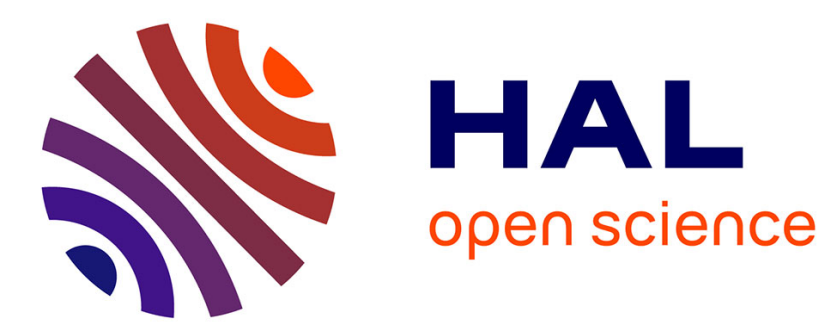

\title{
Functional diversity of nematode communities in the southwestern North Sea
}

M. Schratzberger, K. Warr, S.I. Rogers

\section{To cite this version:}

M. Schratzberger, K. Warr, S.I. Rogers. Functional diversity of nematode communities in the southwestern North Sea. Marine Environmental Research, 2007, 63 (4), pp.368. 10.1016/j.marenvres.2006.10.006 . hal-00501893

\section{HAL Id: hal-00501893 \\ https://hal.science/hal-00501893}

Submitted on 13 Jul 2010

HAL is a multi-disciplinary open access archive for the deposit and dissemination of scientific research documents, whether they are published or not. The documents may come from teaching and research institutions in France or abroad, or from public or private research centers.
L'archive ouverte pluridisciplinaire HAL, est destinée au dépôt et à la diffusion de documents scientifiques de niveau recherche, publiés ou non, émanant des établissements d'enseignement et de recherche français ou étrangers, des laboratoires publics ou privés. 


\section{Accepted Manuscript}

Functional diversity of nematode communities in the southwestern North Sea

M. Schratzberger, K. Warr, S.I. Rogers

PII:

S0141-1136(06)00193-0

DOI:

10.1016/j.marenvres.2006.10.006

Reference:

MERE 3074

To appear in:

Marine Environmental Research

Received Date:

30 January 2006

Revised Date:

5 October 2006

Accepted Date:

19 October 2006

Please cite this article as: Schratzberger, M., Warr, K., Rogers, S.I., Functional diversity of nematode communities in the southwestern North Sea, Marine Environmental Research (2006), doi: 10.1016/j.marenvres.2006.10.006

This is a PDF file of an unedited manuscript that has been accepted for publication. As a service to our customers we are providing this early version of the manuscript. The manuscript will undergo copyediting, typesetting, and review of the resulting proof before it is published in its final form. Please note that during the production process errors may be discovered which could affect the content, and all legal disclaimers that apply to the journal pertain. 
Functional diversity of nematode communities in the southwestern North Sea

M. Schratzberger*, K. Warr, S.I. Rogers

The Centre for Environment, Fisheries and Aquaculture Science, Lowestoft Laboratory, Pakefield

Road, Lowestoft, Suffolk NR33 OHT, United Kingdom

* Corresponding author:

Tel. $+44(0) 1502-527743$

Fax. +44(0)1502-513865

E-mail.m.schratzberger@cefas.co.uk (M. Schratzberger) 


\begin{abstract}
A range of biological traits of nematode species were combined to identify patterns in the functional composition of their assemblages collected at 19 soft-bottom stations in the southwestern North Sea with the primary aim to determine which environmental variables control communities. We used 19 categories of five biological traits thought or known to represent an important ecological function. These were related to buccal morphology, tail shape, body size, body shape and life history strategy. Data on trait membership was provided by biological information on species and genera. A total of 79 different trait combinations were recorded. Results from correlation analyses revealed several significant relationships between traits. Some trait combinations were shared by different species and genera, and the ratio of realised versus total number of possible trait combinations of $<1$ suggested that some trait combinations were not represented by the nematode fauna from this region. The functional composition of nematodes was strongly linked to median particle diameter and silt content of the sediment and water depth. The approach adopted and our attempts at defining and analysing functional attributes of nematode communities raised a number of conceptual and methodological issues which are discussed.
\end{abstract}

Key words: Meiofauna; Free-living nematodes; Community function; Biological traits analysis; North Sea 


\section{Introduction}

Sedimentary habitats cover most of the ocean bottom and therefore constitute the largest single ecosystem on earth in spatial coverage. Benthic organisms which occupy these habitats make a significant contribution to the regulation of carbon, nitrogen and sulphur cycling, water column processes, pollutant distribution and fate, secondary production and transport and stability of sediments (Snelgrove et al., 1997). Four of every five bottom-living multicellular animals on earth are nematodes (Bongers \& Ferris, 1999). Whereas the importance of parasitic nematodes has been recognised for many decades, this is not the case for the free-living species, especially those of aquatic environments. They remain poorly understood, despite the fact that they are extremely abundant and diverse, often numbering millions per square metre in sediments, and occur in more habitats than any other metazoan group (Heip et al., 1985).

The traditional methods of nematode community analyses, deriving diversity and community structure from species abundance data, do not take account of the diverse biology and autecological requirements of the taxa. Natural-history information on nematode species is scant, so studies which require information on nematode ecology have used a functional group approach (Thistle \& Sherman, 1985). Species in functional groups share morphological traits that are thought or known to represent an important ecological function (Chalcraft \& Resetarits, 2003).

Studies on macrobenthic invertebrates have shown that linking taxonomic and functional diversity, i.e. pooling species from different taxonomic entities into functionally similar groups, can reveal different relationships between assemblages (e.g. Bremner et al., 2003; Boström et al., 2006). This suggests that taxonomic and functional analyses should complement each other when deriving general descriptions of benthic diversity, and that using only taxonomic analyses to infer the effects of environmental variables and human activities on biota may omit key functional attributes (Frid et al., 2000; Bremner et al., 2003). 
There are several morphological features of free-living nematodes thought to be related to important ecological functions. In his articles on the ecology of nematodes from European and American coasts, Wieser $(1953,1959)$ showed that the buccal structures of marine nematode genera allow a relatively easy classification into feeding guilds which has since found application in a variety of marine habitats (Giere, 1993 and references therein). Thistle \& Sherman (1985) noted that nematode tails could be important in locomotion and reproduction and proposed a functional grouping of species based on tail shapes. There is inevitably some bias involved in deriving functional characteristics from assumed links to morphology, however, evidence from previous workers suggests that the functional group approach can be valid (e.g. Thistle et al., 1995).

The fitness of a population is a function of physiological as well as ecological features, some of which clearly depend on organism size, such as metabolic rates, the tolerance to chemical stress, the ability to move or migrate and vulnerability to predation (Peters, 1983; Soetaert et al., 2002). Nematode length and width are robust parameters that are easily determined using nondestructive methods and describe important functional attributes of nematode species and genera (Vanhove et al., 1995; Soltwedel et al., 1996; Tita et al. 1999: Soetaert et al., 2002; Vanaverbeke et al. 2003, 2004). Analysing the nematode fauna from a $15 \mathrm{~m}$ deep sandy bottom in the northern part of Öresund, Jensen (1987a) found that species, living in deeper sediment layers were significantly more slender than their oxybiotic, surface-dwelling congeners. He suggested that this morphotype represents adaptations to life in oxygen poor and sulphide rich sediments which is in contrast to previous assumptions that the body length and shape reflect adaptations exclusively to the physical constraints of interstitial space.

Bongers (1990) developed a grouping of nematode genera according to their life history strategies to assess the condition of terrestrial and freshwater habitats. This classification, relating the more r-selected 'colonisers' to the more K-selected 'persisters' has been applied less frequently to marine nematodes (Bongers et al., 1991; Fraschetti et al., 2006), partly due to a lack of empirical 
support for the classification of some marine genera and the absence or rarity of extreme colonisers and persisters in most marine habitats.

The reduction of a generally high species diversity into a smaller number of single functional groups, suggesting a very limited functional diversity, risks underestimating the true functional complexity of nematode communities (Thistle et al., 1995). In this paper we address this by combining a range of biological traits of nematode species and genera describing buccal morphology, tail shape, body size, body shape and life history strategy to identify patterns in the functional diversity of nematodes from the southwestern North Sea. Taxonomic and functional aspects of nematode communities at 19 stations were investigated. The following questions were posed:

(1) Which environmental factors explain the number and composition of nematode functional groups?

(2) What is the degree and importance of redundancy, i.e. multiple species/genera per biological trait?

(3) How useful is the functional group concept and the biological traits approach in the study of nematodes in benthic soft-bottom ecosystems compared to their taxonomic properties?

\section{Materials and Methods}

\subsection{Study site and sample collection}

Sediment samples were collected at 19 stations in the southwestern North Sea (Fig. 1). All locations were sampled in May 2000, except of station 5, 6 and 9 where samples were collected in May 2001. All stations studied were located away from anthropogenic point-source impacts. The closest dredgings disposal site, for example, was located approximately $14 \mathrm{~km}$ west off station 1 while the nearest oil and gas well was found about $750 \mathrm{~m}$ off station 3 . 
At each station, three replicate samples were taken with a $0.1 \mathrm{~m}^{2}$ day grab from within a $100 \mathrm{~m}$ range ring (using SEXTANT ${ }^{\mathrm{TM}}$ software and DGPS position fixing). From each deployment, two sub-samples, one for particle size and organic carbon content analysis and one for the study of meiofauna, were collected with a perspex corer $(3 \mathrm{~cm}$ diameter) to a depth of $5 \mathrm{~cm}$. Only two valid replicates could be retrieved from station 4, 14 and 15. All meiofauna samples were fixed in $5 \%$ formaldehyde in $63 \mu \mathrm{m}$ filtered seawater and samples for particle size and organic carbon content analysis were frozen to a temperature of $-20{ }^{\circ} \mathrm{C}$ pending analysis.

\subsection{Sample processing}

One replicate sample collected for the analysis of environmental variables was processed per station. Sediment granulometry was determined by a combination of dry sieving and laser sizing to give the full particle size distribution (Dyer, 1986). Organic carbon content of the sediment fraction $<63 \mu \mathrm{m}$ was determined with a Leeman CE 440 elemental analyser.

Meiofauna samples were initially washed onto a $63 \mu \mathrm{m}$ sieve to remove the fine silt fraction and the formalin. After decanting the samples five times onto a $63 \mu \mathrm{m}$ sieve, meiofauna was extracted with Ludox ${ }^{\mathrm{TM}} 40$ with a specific gravity of 1.15 (Somerfield \& Warwick, 1996). The extraction process was repeated three times. The extracts were evaporated slowly in anhydrous glycerol and evenly spread on microscope slides for identification and counting of nematodes under a highpower microscope (Olympus BX 51) with Nomarski interference contrast illumination. All nematodes in each sample were analysed to species or genus level. 


\subsection{Data processing}

\subsubsection{Treatment of raw data}

A total of 169 nematode species were recorded in the southwestern North Sea (Schratzberger et al., 2006). Nematode species and genera were classified according to their buccal morphology, tail shape, adult length, adult shape and life history strategy.

Buccal morphology:

Free-living marine nematodes display a high diversity in the structure of their mouth cavity. Based on these morphological characteristics, Wieser (1953) devised a classification of feeding types including selective deposit feeders consuming bacteria and small-sized organic particles (1A), non-selective deposit feeders also feeding on organic deposit but targeting larger-sized particles (1B), epigrowth feeders scraping food off surfaces similar to macrobenthic grazers (2A), and predators feeding on nematodes and other small invertebrates (2B). Although various authors have later revised and modified this classification (Romeyn \& Bouwman, 1983; Jensen, 1987b; Moens \& Vincx, 1997; Moens et al., 2004), nematode genera were assigned to Wieser's (1953) feeding guilds since this remains the only scheme available that considers free-living marine nematodes from a variety of habitats.

\section{Tail shape:}

In addition to the functional grouping of feeding types, other aspects of nematode morphology can provide alternative functional group classifications. In their study of deep sea nematodes from the North Atlantic, Thistle \& Sherman (1985) pioneered a scheme based on tail shape. Tail types are diverse and variable and tail and buccal morphology together have proven to be an effective method to discriminate nematode communities (Thistle et al., 1995). Tail shapes for nematode 
species recorded in the southwestern North Sea were taken from the taxonomic description of species and genera. Nematodes were assigned to four tail shape groups, common in free-living marine nematodes from coastal environments (short/round, elongated/filiform, conical, clavate).

Adult length and adult shape:

Similar to tail shape, the total length and the length-width ratios for adult nematode species were deduced from the taxonomic literature. Although simple measures of length and width cannot do justice to the wide morphological variation amongst free-living nematodes, they can offer a unique opportunity for evaluating the impact of environmental variables on their populations and assemblages (Soetaert et al., 2002). The length-width ratio is a measure of a nematode's body shape with long/thin animals having high ratios, stout animals low ratios. Soetaert et al. (2002) suggested that three morphologies have developed over evolutionary time-scales: Stout, slender and long/thin. Slender and long/thin nematodes are able to move swiftly through the sediment, but small, juvenile stages are vulnerable to predation. The stout morphotype, in contrast, may have evolved towards reducing this predation pressure on the small individuals but these adaptations undoubtedly bring about reduced mobility. Nematode species were assigned to four length groups ( $<1 \mathrm{~mm}, 1-2 \mathrm{~mm}, 2-4 \mathrm{~mm},>4 \mathrm{~mm}$ ) and three shape categories (stout with a length-width ratio $<18$, slender with a length-width ratio of 18-72 and long/thin with a lengthwidth ratio $>72$ ) which are thought to conform as closely as possible to likely functions.

\section{Life history strategy:}

A number of attempts to investigate the life cycles of marine nematodes by examining the age structure or size frequency throughout the year are reported in the literature (Warwick \& Price, 1979). Analyses of this kind are successful only if the reproductive cycles of individuals in the population are synchronised and the number of annual generations is relatively small to avoid confusion through excessive overlap in generations (Wieser \& Kanwisher, 1960). However, 
culture experiments have shown that many small species have short generation times of usually about one month or less (Gerlach, 1971; Heip et al., 1985). Nematodes were allocated to life history groups according to Bongers (1990) and Bongers et al. (1991, 1995) where genera are classified on a five-point scale from colonisers (inter alia short life-cycle, high reproduction rates, high colonisation ability, tolerant to various types of disturbance) to persisters (inter alia long life-cycles, low colonisation ability, few offspring, sensitive to disturbance). In contrast to terrestrial environments, extreme colonisers (coloniser-persister score of 1) and persisters (coloniser-persister score of 5) are virtually absent in marine systems.

\subsubsection{Biological traits analysis}

A biological traits analysis, following the approach described for macrobenthic communities (Frid et al., 2000; Bremner et al., 2003) was carried out to assess the functional structure of nematode communities in the southwestern North Sea. Five traits were used, buccal morphology, tail shape, adult length, adult shape and life history strategy. There were a total of 19 categories of these traits, as described above. A biological traits matrix was constructed by assigning to each nematode species/genus its affinity to each trait category (Appendix). The biological traits matrix was then raised by the relative species abundance to give abundance-weighted traits matrices for each station.

One of the problems associated with assigning species/genera to biological trait categories is that all species allocated to a particular biological trait may not be equivalent in the degree to which they express this trait (Petchey \& Gaston, 2002). Species within a particular trait group, however, are more similar in the extent to which they display a particular trait (Chalcraft \& Resetarits, 2003). Biological traits analysis relies on the ecological importance and accuracy of measurement of all the different functionality measures that are selected for use. In this analysis, we apply 
equal weighting to all traits due to the lack of information on their relative importance, and only use traits that were considered potentially important by the authors of primary literature.

\subsubsection{Analysis of nematode distribution patterns}

Non-metric multi-dimensional scaling (MDS) ordination using the Bray-Curtis similarity measure was applied to relative abundance data to compare spatial patterns in the taxonomic and functional composition of nematode communities at the 19 sampling locations. Separate resemblance matrices were created based on the composition of the nematode communities with respect to species and genus identity, buccal morphology, tail shape, adult length, adult shape and coloniser-persister score. A further resemblance matrix was created based on the abundanceweighted biological traits matrix to summarise patterns in the functional structure of nematode assemblages of all species. Analysis of similarities (ANOSIM) was used to test for significant taxonomic and functional differences between stations and the Similarity Percentages (SIMPER) procedure was applied to identify the trait groups that were primarily responsible for the functional differences observed between locations.

Resemblance matrices derived from the species and genus abundance matrix, the single functional group matrices and the biological traits matrix were used in a second-stage MDS analysis to examine similarities between each of the first-stage MDS matrices (Somerfield \& Clarke, 1995). By means of this technique, Spearman rank correlations $\left(\mathrm{r}_{\mathrm{s}}\right)$ calculated between pairs of similarity matrices are used as a basis for a second-stage MDS ordination. The proximity of the points in the resultant MDS ordination indicates the extent to which different analysis options capture the same information.

Five environmental parameters were included in the data analyses (median particle diameter, total organic carbon and silt content, sorting coefficient and water depth) together with a derived measure of sediment heterogeneity following Ward (1975): 


$$
\begin{array}{ll}
\mathrm{h}= & \mathrm{QD} \varnothing=\text { = Sorting coefficient } \\
\hline \mathrm{Md} \varnothing \mathrm{x} \% \text { silt } & \mathrm{Md} \varnothing=\text { Median particle diameter [phi] }
\end{array}
$$

The concentrations of trace metals in the sediment were low at all stations and an unlikely cause of biological effects (see Schratzberger et al., 2006). Trace metal concentrations were therefore omitted from the correlation analyses.

The relationship between the structure of nematode assemblages and environmental variables was explored by calculating Spearman rank correlations $\left(\mathrm{r}_{\mathrm{s}}\right)$ between similarity matrices derived from the faunal data (based on Bray-Curtis similarity) and matrices derived from various subsets of environmental data (based on normalised Euclidean Distance), thereby defining suites of environmental variables which best explained the biotic structure (BIOENV procedure). A permutation test was applied to assess the significance of these relationships.

All statistical analyses were performed using the software packages Statgraphics Plus version 3.3 and Primer version 6.1.5 (Clarke \& Warwick, 1994, Clarke \& Gorley, 2006).

\section{Results}

The study area comprised a stable, sedimentary environment increasing significantly in depth to the north and east. Most of the sediments collected consisted of moderately to poorly sorted muddy sands. The finest and most uniform substrates with the highest silt content (station 1 and 13) were found in the northern part of the study area while the coarsest, most heterogeneous sediments with lowest silt content (station 14 to 19) were located in the south (Table 1).

Functional attributes of nematode communities in the southwestern North Sea are listed in Table 2 and 3. Assemblages were dominated by non-selective deposit feeders (1B) and epigrowth 
feeders (2A) whereas proportions of selective deposit feeders (1A) and predators (2B) were comparatively low at most stations. Conical and clavate were the most prevalent tail shapes at the majority of stations (Table 2). Average adult lengths of nematodes ranged from $0.35 \mathrm{~mm}$ to 12 $\mathrm{mm}$ with the majority of all recorded individuals (76\%) occurring in the two intermediate length classes (1-2 mm and 2-4 mm). Three nematode morphotypes were present in the sediments. The majority of nematodes were slender $(82 \%)$ while stout animals accounted for $6 \%$ and long/thin animals for $12 \%$ of all nematodes identified. Over $81 \%$ of all identified individuals attained a coloniser-persister score of 2 or 3 . Extreme persisters (coloniser-persister score of 5), in contrast were either absent or rare (Table 3).

A total of 79 trait combinations were represented amongst the nematode fauna of the southwestern North Sea (Appendix). The biological traits matrix revealed several notable relationships between traits. For example, large-bodied nematodes generally had a high coloniserpersister score while that for smaller species was low. Equally, in contrast to the generally smallsized selective deposit feeders, predators were usually large. While ecologically implausible trait combinations such as, for example, small body size combined with a K-selected life history strategy (i.e. high coloniser-persister score) were absent from the nematode communities of the southwestern North Sea, the traits matrix revealed some combinations of functional groups to which no species belonged (e.g. no epigrowth feeders with rounded tails), although these combinations are known from other environments. The spatial pattern of mean number of biological trait groups mirrored the pattern of mean species and mean genus number (Fig. 2).

Assemblages collected at the 19 stations differed both taxonomically and functionally (Table 4) but the ordinations of taxonomic groups did not match the ordinations based on functional groups and traits (Fig. 3). In the ordinations based on the relative abundance of nematode species and genera, stations in the northern part of the study site tended to cluster to the left while the southern stations were grouped to the right. This geographic separation was less pronounced in the ordinations derived from functional characteristics of nematode communities. We observed a 
high dominance of non-selective deposit feeders (1B) and epigrowth feeders (2A) at station 13 and 17 respectively and nematode communities collected at station 1 and 13 were highly dominated by individuals with an elongated/filiform tail. In contrast to other functional groups, the separation of nematode assemblages based on their adult length and shape was comparatively low with Bray-Curtis similarities between stations exceeding $80 \%$. High proportions of colonisers (coloniser-persister score of 2) prevailed at station 13, whereas more K-selected species (coloniser-persister score of 3 and 4) were abundant at other stations. Station 13 diverged notably from other locations when a wider range of biological traits expressed by species and genera was considered (Fig. 3). Two trait combinations were primarily responsible for the difference between this comparatively deep, silty site and other sampling stations. The trait combination selective deposit feeder/clavate tail/1-2 $\mathrm{mm} / \mathrm{slender/coloniser-persister} \mathrm{score} 2$ dominated station 13, whereas species combining a similar length, shape and colonisation potential with an epigrowth feeding habit and a conical tail occurred in high proportions at other locations. These two discriminating trait combinations were the most species-rich. Eighteen species belonging to the comesomatids, xyalids, linhomoeids and axonolaimids shared the same trait combinations in the first group while a total of 15 desmodorid, microlaimid, chromadorid and cyatholaimid species were abundant in the latter. Forty eight species each had a combination of trait categories that was unique only to them (Appendix). A high proportion of one of these trait groups (represented by Leptonemella aphanothecae), combining a selective deposit feeding habit, conical tail, relatively long and thin body with a high coloniser-persister score of 4 , distinguished nematode communities at station 12 from those at other locations.

The similarity of the spatial groupings of the 19 sampling stations is illustrated by a second-stage MDS based on Spearman rank correlations $\left(\mathrm{r}_{\mathrm{s}}\right)$ of the eight underlying similarity matrices (Fig. 4). The ordination revealed that 
- The information in a particular functional group was not a simple reflection of the information in another group (i.e. matrices based on single functional groups such as buccal morphology, tail shape etc. clustered separately from each other).

- Clumping of species and genera into combined biological traits increased the relative importance of the taxonomic community composition (i.e. the biological traits matrix clustered closest to matrices derived from the species and genus composition).

- Ecological information captured by adult length, adult shape and life history strategy was less site-specific and thus differed notably from information contained in other functional groups.

With the exception of tail shape, which was significantly related to the silt content of the sediment, none of the relationships between functional groups and measured environmental factors was significant at $\mathrm{p}<0.05$ (Table 5). Nematode distribution patterns based on proportions of species and genera were strongly linked to sediment heterogeneity, a derived measure combining sorting coefficient, median particle diameter and silt content. The composition of assemblages in terms of biological traits was best explained by a combination of factors related to sediment granulometry (median particle diameter and silt content) and water depth (Table 5). The number of species, genera and trait groups generally increased with increasing water depth and decreased with increasing mean particle diameter and sediment heterogeneity.

\section{Discussion}

Functional diversity, the extent of functional differences among the species in a community, is an important determinant of ecosystem processes. A common measure of functional diversity is the number of functional groups represented by the species in a community (Petchey \& Gaston, 2002). In this article we described nematode assemblages on the basis of the functional attributes of species and genera, and showed how the functionally-defined assemblages varied spatially in 
response to environmental variables. To our knowledge, very few attempts have been made to understand the environmental factors which determine functional diversity of meiobenthic nematodes at regional scales. We posed three questions in the introduction related to practical and philosophical issues surrounding the assessment of functional diversity in nematode communities. These questions are addressed in the light of the outcome from the analysis of faunal and environmental data collected at 19 stations in the southwestern North Sea.

4.1 Which environmental factors explain the number and composition of nematode functional groups?

In a previous article Schratzberger et al. (2006) gave a detailed account of the species distribution patterns, diversity and community structure of nematode assemblages collected at the 19 sampling stations. Assemblages showed a characteristic pattern in the multivariate ordination, with stations grouped in two big clusters, one consisting of the deeper, fine sediment, northern stations (station 1 to 13 ), the other including the shallower, coarser sediment southern stations (station 14 to 19). These groups exhibited clear differences in species diversity, and stations with similar sediment type and water depth were also most similar taxonomically. Sediment-related factors were also important for morphological characteristics of species and genera that have been shown to be of functional importance.

Of all single functional groups, spatial dissimilarities in tail shape and buccal morphology were the most pronounced. Tail morphology showed a clear link to the silt content of the sediment. Species with elongated/filiform tails were disproportionally abundant at station 1 and 13 where the siltiest sediments occurred. Rieman (1974) reported that some individuals with a long, filiform tail have a partly sessile existence in which tail morphology plays a crucial role. He suggested that this is a special adaptation to fine sand and muddy sediments where only an incomplete interstitial system exists. In these sediments, the tail would enable animals to retract 
from dead-end interstitial passageways that are too narrow to allow the worm to turn around and escape.

In contrast to tail morphology, there was no evidence of association between the relative abundance of buccal morphology groups and variation in measured environmental variables. We therefore hypothesise that other, unmeasured sediment-related environmental variables might be important for the functional structure of assemblages (e.g. input of organic material). The association between trophic structure of nematode communities and the carbon content in the sediment was weak, and chlorophyll $a$ content in the sediment was not measured in our study. However, it has been shown that during the deposition of a phytoplankton bloom in the southern North Sea between April and June, the chlorophyll $a$ content in the water column closely follows pigment concentrations in the bottom water (Vanaverbeke et al., 2004). In 2000 and 2001, the chlorophyll $a$ content in the vicinity of some of our sampling stations was determined at a depth of $4 \mathrm{~m}$ between May and August (N. Greenwood unpubl. data). Lowest chlorophyll $a$ concentrations were recorded at station 13 , highest at station 17 and these were clearly linked to a low and high prevalence of epigrowth feeding nematodes respectively.

At station 13, a low median particle diameter, high silt content and water depth were indicative of a relatively high consistency of physico-chemical factors. These environmental conditions were coupled with a dominance of species combining a selective deposit feeding habit, clavate tail, intermediate-sized, slender body with a high colonisation potential. Sediments with high silt content generally show a high portion of deposit-feeders (Heip et al., 1985), and these often score 2 or 3 on the coloniser-persister axis (Bongers et al., 1991, 1995). It is therefore possible that a relatively un-specialised feeding group of nematodes, characterised by short life cycles and a high colonisation ability was able to exploit prevailing environmental conditions at this station. 
4.2 What is the degree and importance of redundancy, i.e. multiple species/genera per functional group?

The 169 nematode species identified in the southwestern North Sea had 79 different combinations of biological traits, and 33 species shared the two most common combinations of traits. To some extent, this pattern has been caused by the allocation of nematodes to only 19, partly interrelated, functional groups. The functional groups used represent the major trophic and morphological categories available to the phylum, and each could be sub-divided further to provide more species with unique combinations of traits. Although it is unlikely that further sub-division of existing traits would be meaningful, it is unclear whether the inclusion of additional traits, for example related to the physiology (e.g. respiration rates, Warwick \& Price, 1979) of species, would provide greater differentiation in the functional roles of nematodes.

We observed a strong link between species and genus counts and the number of functional traits supporting the contention that, under a constant set of environmental conditions, an increase in species richness (i.e. number of species) should lead to increased functional diversity.

Spatial patterns in the functional structure of assemblages were primarily related to differences in the two most species-rich trait combinations, shared by 18 and 15 species respectively. These trait combinations included both dominant and low-abundance species with different taxonomic affiliation. Walker et al. (1999) hypothesised that many of the low-abundance species are analogues of the dominants with respect to their ecological functions. They differ in terms of their capabilities to respond to environmental stresses and disturbance, thereby conferring resilience on the community. Environmental conditions thus influence the importance of functional complementarity in structuring communities (Hooper et al., 2005).

Concepts of niche differentiation imply that functional characteristics of coexisting organisms must differ at some level, but the identification of which and how many species act in a complementary way in complex communities is just beginning (Hooper et al., 2005). There may 
be species that can be lost from some ecosystems without substantial alteration of ecosystem function, as two species (for example Nannolaimoides effilatus and Terschellingia gourbaultae, see Appendix) can show similarities in the way they feed, reproduce and move within the habitat. However, they probably do not carry out these activities in exactly the same way or at the same time, and the functional significance of these differences, not recorded by this analysis, is likely to depend on the species and ecosystem in question (Snelgrove, 1999).

To date, few studies have tested the concept of functional redundancy in free-living nematode communities (Mikola \& Setälä, 1998; De Mesel et al., 2003). These investigations into the contribution of species to ecosystem processes revealed effects of individual species rather than functional groups (e.g. feeding types). A more reliable approach to assessing the functional structure of nematode communities might therefore be to consider combinations of biological traits expressed by organisms (i.e. biological traits analysis) rather than relying on single functional groups. Postma-Blaauw et al. (2005), for example, showed that differences in life history strategies between nematode species of the same trophic group is of importance for their communal effect on soil ecosystem processes.

4.3 How useful is the functional group concept and the biological traits approach in the study of nematodes in benthic soft-bottom ecosystems compared to their taxonomic properties?

Results from the ANOSIM analyses indicated that spatial differences of combined biological traits were more pronounced than dissimilarities based on the proportions of individuals from single functional groups. Although the biological traits approach is no more powerful than traditional taxonomic methods in detecting spatial differences between communities, it is of additional ecological importance. The outcome from multivariate analyses confirmed that the ecological information captured by the biological traits matrix was not a simple reflection of the information contained in single functional groups. Consequently, combining a number of 
functionality measures in one biological traits analysis provided ecological information that could not have been discerned from the separate analysis of functionally important morphologies. For example, although station 13 showed a characteristic spatial pattern with respect to some functional groups, the functional differences between this and other locations could be most reliably linked to measured environmental variables only when the biological traits approach was applied.

Functional diversity is an important component of biodiversity, yet in comparison to taxonomic diversity, methods of quantifying functional diversity are less well developed (Petchey \& Gaston, 2002). Our results from the second-stage MDS showed that assigning species and genera to biological traits provided additional insights to those from traditional taxonomic analyses. This suggests that measures based on a phylogenetic classification do not alone capture all of the important, heritable differences in nematode attributes (Walker et al., 1999). Improving our understanding of diversity-function relationships across ecosystems will require a categorisation of species attributes that can be related to function. Consequently, obtaining a greater knowledge of the functional roles of nematode species will be the key to improve the sensitivity and interpretation of biological traits analyses of marine benthic communities.

\section{Acknowledgements}

We thank members of the Centre for Environment, Fisheries and Aquaculture Science and the officers and crew of RV 'Cirolana' for practical assistance in the collection of samples. Claire Mason conducted the particle size analyses. Comments of two anonymous referees significantly improved an earlier version of the manuscript. The work was supported by the Department for Environment, Food and Rural Affairs (research project AE002 and AE1148).

\section{References}


Bongers, T. (1990) The maturity index: an ecological measure of environmental disturbance based on nematode species composition. Oecologia, 83, 14-19.

Bongers, T., Alkemade, R., \& Yeates, G.W. (1991) Interpretation of disturbance-induced maturity decrease in marine nematode assemblages by means of the Maturity Index. Marine Ecology Progress Series, 76, 135-142.

Bongers, T., de Goede, R.G.M., Korthals, G.W., \& Yeates, G.W. (1995) Proposed changes of c-p classification for nematodes. Russian Journal of Nematology 3, 61-62.

Bongers, T., \& Ferris, H. (1999) Nematode community structure as a bioindicator in environmental monitoring. Tree, 14, 224-228.

Boström, C., O'Brien, K., Roos, C., \& Ekebom, J. (2006) Environmental variables explaining structural and functional diversity of seagrass macrofauna in an archipelago landscape. Journal of Experimental Marine Biology and Ecology 335, 52-73.

Bremner, J., Rogers, S.I., \& Frid, C.L.J. (2003) Assessing functional diversity in marine benthic ecosystems: a comparison of approaches. Marine Ecology Progress Series, 254, 11-25.

Chalcraft, D. R. \& Resetarits, W. J. (2003) Mapping functional similarity of predators on the basis of trait similarities. American Naturalist 162, 390-402.

Clarke, K.R., \& Warwick, R.M. (1994) Change in marine communities: an approach to statistical analysis and interpretation. Plymouth, UK: Plymouth Marine Laboratory, 144 pp.

Clarke, K.R. \& Gorley, R.N. (2006) PRIMER version 6. User Manual. PRIMER-E Ltd, Plymouth, UK, 190 pp.

De Mesel, I., Derycke, S., Swings, J., Vincx, M., \& Moens, T. (2003) Influence of bacterivorous nematodes on the decomposition of cordgrass. Journal of Experimental Marine Biology and Ecology 296, 227-242.

Dyer, K.R. (1986) Coastal and estuarine sediment dynamics. Chichester, UK: John Wiley \& Sons, $342 \mathrm{pp}$. 
Fraschetti, S., Gambi, C., Giangrande, A., Musco, L., Terlizzi, A., \& Danovaro, R. (2006)

Structural and functional response of meiofauna rocky assemblages to sewage pollution. Marine Pollution Bulletin 52, 540-548.

Frid, C.L.J., Rogers, S.I., Nicholson, M., Ellis, J.R., \& Freeman, S. (2000) Using biological characteristics to develop new indices of ecosystem health. ICES, Copenhagen, Denmark: Mini-symposium on defining the role of ICES in supporting biodiversity conservation.

Gerlach, S.A. (1971) On the importance of marine meiofauna for benthos communities. Oecologia, 6, 176-190.

Giere, O. (1993). Meiobenthology - the microscopic fauna in aquatic sediments. Berlin, Germany: Springer Verlag, 328 pp.

Heip, C., Vincx, M., \& Vranken, G. (1985) The ecology of marine nematodes. Oceanography and Marine Biology: an Annual Review, 23, 399-489.

Hooper, D.U., Chapin, F.S., Ewel, J.J., Hector, A., Inchausti, P., Lavorel, S., Lawton, J.H., Lodge, D.M., Loreau, M., Naeem, S., Schmid, B., Setälä, H., Symstad, A. J., Vandermeer, J., \& Wardle, D.A. (2005) Effects of biodiversity on ecosystem functioning: a consensus of current knowledge. Ecological Monographs 75, 3-35.

Jensen, P. (1987a) Differences in microhabitat, abundance, biomass and body size between oxybiotic and thiobiotic free-living marine nematodes. Oecologia, 71, 564-567.

Jensen, P. (1987b) Feeding ecology of free-living aquatic nematodes. Marine Ecology Progress Series, 35, 187-196.

Mikola, J. \& Setälä, H. (1998) Relating species diversity to ecosystem functioning: mechanistic backgrounds and experimental approach with a decomposer food web. Oikos 83, 180-194.

Moens, T., \& Vincx M. (1997) Observations on the feeding ecology of estuarine nematodes. Journal of the Marine Biological Association of the United Kingdom, 77, 211-227.

Moens, T., Yeates, G.W., \& De Ley, P. (2004) Use of carbon and energy sources by nematodes. Nematology Monographs and Perspectives 2, 529-545. 2004. 
Petchey, O.L. \& Gaston, K.J. (2002) Functional diversity (FD), species richness and community composition. Ecology Letters 5, 402-411. 2002.

Peters, R.H. (1983) The ecological implications of body size. Cambridge, UK: Cambridge University Press, 329 pp.

Postma-Blaauw, M.B., de Vries, F.T., de Goede, R.G.N., Bloem, J., Faber, J. H., \& Brussaard, L. (2005) Within-trophic group interactions of bacterivorous nematode species and their effects on the bacterial community and nitrogen mineralization. Oecologia 142, 428-439.

Riemann, F. (1974) On hemisessile nematodes with flagilliform tails living in marine soft bottoms and on microtubes found in deep sea sediments. Mikrofauna des Meeresbodens, 40, $1-15$.

Romeyn, K., \& Bouwman, L.A. (1983) Food selection and consumption by estuarine nematodes. Hydrobiological Bulletin, 17, 103-109.

Schratzberger, M., Warr, K., \& Rogers, S.I. (2006). Patterns of nematode populations in the southwestern North Sea and their link to other components of the benthic fauna. Journal of Sea Research, 55, 113-127.

Snelgrove, V.R., Blackburn, T.H., Hutchings, P.A., Alongi, D.M., Grassle, J.F., Hummel, H., King, G., Koike, I., Lambshead, P.J.D., Ramsing, N.B., \& Solis-Weiss, V. (1997) The importance of marine sediment biodiversity in ecosystem processes. Ambio, 26, 578-583.

Snelgrove, V.R. (1999) Getting to the bottom of marine biodiversity: sedimentary habitats. Bioscience, 49, 129-138.

Soetaert, K., Muthumbi, A., \& Heip, C. (2002) Size and shape of ocean margin nematodes: morphological diversity and depth-related patterns. Marine Ecology Progress Series, 242, 179-193.

Soltwedel, T., Pfannkuche, O., \& Thiel, H. (1996) The size structure of deep-sea meiobenthos in the North-Eastern Atlantic: nematode size spectra in relation to environmental variables. Journal of the Marine Biological Association of the United Kingdom, 76, 327-344. 
Somerfield, P.J., \& Clarke, K.R. (1995) Taxonomic levels, in marine community studies, revisited. Marine Ecology Progress Series, 127, 113-119.

Somerfield, P.J., \& Warwick, R.M. (1996) Meiofauna in marine pollution monitoring programmes. A laboratory manual. Lowestoft, UK: Ministry of Agriculture, Fisheries and Food, Directorate of Fisheries Research, 71 pp.

Thistle, D. \& Sherman, K.M. (1985) The nematode fauna of a deep-sea site exposed to strong near-bottom currents. Deep-Sea Research 32, 1077-1088.

Thistle, D., Lambshead, P.J.D. \& Sherman, K.M. (1995) Nematode tail-shape groups respond to environmental differences in the deep sea. Vie et Milieu 45, 107-115.

Tita, G., Vincx, M., \& Desrosiers, G. (1999) Size spectra, body width and morphotypes of intertidal nematodes: an ecological interpretation. Journal of the Marine Biological Association of the United Kingdom, 79, 1007-1015.

Vanaverbeke, J., Steyaert, M., Vanreusel, A., \& Vincx, M. (2003) Nematode biomass spectra as descriptors of functional changes to human and natural impact. Marine Ecology Progress Series, 249, 157-17.

Vanaverbeke, J., Soetaert, K., \& Vincx, M. (2004) Changes in morphometric characteristics of nematode communities during a spring phytoplankton bloom deposition. Marine Ecology Progress Series, 273, 139-146.

Vanhove, S., Wittoeck, J., Desmet, G., van den Berghe, E., Herman, R.L., Bak, R.P.M., Nieuwland, G., Vosjan, J.H., Boldrin, A., Rabitti, S., \& Vincx, M. (1995) Deep-sea meiofauna communities in Antarctica: structural analysis in relation with the environment. Marine Ecology Progress Series, 127, 65-76.

Walker, B., Kinzig, A., \& Landridge, J. (1999) Plant attribute diversity, resilience, and ecosystem function: the nature and significance of dominant and minor species. Ecosystems 2, 95-113. 


\section{ACCEPTED MANUSCRIPT}

Ward, A.R. (1975) Studies on the free-living marine nematodes of Liverpool Bay. II. Influence of sediment composition on the distribution of marine nematodes. Marine Biology, 30, 217 225.

Warwick, R.M., \& Price, R. (1979) Ecological and metabolic studies on free-living nematodes from an estuarine mud-flat. Estuarine and Coastal Marine Science, 9, 257-271.

Wieser, W. (1953) Die Beziehung zwischen Mundhöhlengestalt, Ernährungsweise und Vorkommen bei freilebenden marinen Nematoden. Arkiv för Zoologi, 4, 439-484.

Wieser, W. (1959) The effect of grain size on the distribution of small invertebrates inhabiting the beaches of Puget Sound. Limnology and Oceanography, 4, 181-194.

Wieser, W., \& Kanwisher, J.W. (1960) Growth and metabolism in a marine nematode Enoplus communis Bastian. Zeitschrift für vergleichende Physiologie, 43, 29-36. 
Table 1

Location of and environmental parameters at 19 stations in the southwestern North Sea

\begin{tabular}{|c|c|c|c|c|c|c|c|c|}
\hline Station & Latitude & Longitude & $\begin{array}{l}\text { Depth } \\
{[\mathrm{m}]}\end{array}$ & $\begin{array}{c}\text { Median } \\
{[\mu \mathrm{m}]}\end{array}$ & $\begin{array}{l}\text { Silt } \\
{[\%]}\end{array}$ & $\begin{array}{c}\text { Sorting } \\
\text { coefficient }\end{array}$ & $\begin{array}{c}\text { Sediment } \\
\text { heterogeneity } \mathrm{h}\end{array}$ & $\begin{array}{c}\mathrm{C} \\
{[\%]}\end{array}$ \\
\hline 1 & $55.00 \mathrm{~N}$ & $1.00 \mathrm{~W}$ & 78 & 110 & 15.6 & $\begin{array}{r}2.3 \\
\end{array}$ & 0.05 & no data \\
\hline 2 & $55.00 \mathrm{~N}$ & 0.00 & 76 & 184 & 7.3 & 1.8 & 0.10 & 3.0 \\
\hline 3 & $54.75 \mathrm{~N}$ & $0.50 \mathrm{~W}$ & 64 & 143 & 3.1 & 1.0 & 0.11 & 4.8 \\
\hline 4 & $54.75 \mathrm{~N}$ & $0.50 \mathrm{E}$ & 78 & 122 & 2.8 & 1.1 & 0.12 & 3.5 \\
\hline 5 & $54.75 \mathrm{~N}$ & $1.50 \mathrm{E}$ & 26 & 167 & 1.1 & 1.4 & 0.50 & 3.7 \\
\hline 6 & $54.75 \mathrm{~N}$ & $2.50 \mathrm{E}$ & 40 & 127 & 3.5 & 1.2 & 0.12 & 2.8 \\
\hline 7 & $54.50 \mathrm{~N}$ & 0.00 & 67 & 160 & 2.1 & 1.1 & 0.19 & 5.2 \\
\hline 8 & $54.50 \mathrm{~N}$ & $1.00 \mathrm{E}$ & 61 & 212 & 1.3 & 1.0 & 0.35 & 4.9 \\
\hline 9 & $54.50 \mathrm{~N}$ & $2.00 \mathrm{E}$ & 20 & 173 & 1.0 & 1.4 & 0.56 & 3.8 \\
\hline 10 & $54.25 \mathrm{~N}$ & $0.50 \mathrm{E}$ & 66 & 210 & 1.3 & 1.0 & 0.34 & 4.6 \\
\hline 11 & $54.25 \mathrm{~N}$ & $1.50 \mathrm{E}$ & 54 & 157 & 3.3 & 1.2 & 0.13 & 2.9 \\
\hline 12 & $54.00 \mathrm{~N}$ & $1.00 \mathrm{E}$ & 44 & 145 & 2.5 & 1.0 & 0.14 & 3.5 \\
\hline 13 & $54.00 \mathrm{~N}$ & $2.00 \mathrm{E}$ & 76 & 117 & 14.5 & 1.7 & 0.04 & 1.9 \\
\hline 14 & $53.75 \mathrm{~N}$ & $1.50 \mathrm{E}$ & 60 & 374 & 0.8 & 1.4 & 1.18 & 2.3 \\
\hline 15 & $53.50 \mathrm{~N}$ & $2.00 \mathrm{E}$ & 23 & 316 & 0.7 & 0.7 & 0.62 & 3.4 \\
\hline 16 & $53.25 \mathrm{~N}$ & $2.50 \mathrm{E}$ & 32 & 202 & 1.4 & 0.8 & 0.25 & 2.2 \\
\hline 17 & $53.00 \mathrm{~N}$ & $1.00 \mathrm{E}$ & & 262 & 1.5 & 1.0 & 0.33 & no data \\
\hline 18 & $52.75 \mathrm{~N}$ & $2.50 \mathrm{E}$ & 42 & 339 & 0.9 & 1.4 & 1.02 & 1.6 \\
\hline 19 & $52.25 \mathrm{~N}$ & $2.50 \mathrm{E}$ & 45 & 337 & 0.3 & 1.4 & 3.20 & 2.5 \\
\hline
\end{tabular}


Table 2

Relative abundance (mean $\pm \mathrm{SE}$ ) of nematodes in buccal morphology and tail shape categories at 19 stations in the southwestern North Sea. $1 \mathrm{~A}=$ selective deposit feeders, $1 \mathrm{~B}=$ non-selective deposit feeders, $2 \mathrm{~A}=$ epigrowth feeders, $2 \mathrm{~B}=$ predators (Wieser, 1953)

\begin{tabular}{|c|c|c|c|c|c|c|c|c|}
\hline \multirow[t]{2}{*}{ Station } & \multicolumn{4}{|c|}{ Buccal morphology } & \multicolumn{4}{|c|}{ Tail shape } \\
\hline & $1 \mathrm{~A}$ & $1 \mathrm{~B}$ & $2 \mathrm{~A}$ & $2 \mathrm{~B}$ & short/round & elongated/filiform & conical & clavate \\
\hline 1 & $19 \pm 6$ & $35 \pm 3$ & $36 \pm 4$ & $10 \pm 4$ & $3 \pm 4$ & $28 \pm 5$ & $26 \pm 5$ & $44 \pm 3$ \\
\hline 2 & $9 \pm 2$ & $36 \pm 6$ & $47 \pm 4$ & $9 \pm 1$ & $0 \pm 0$ & $10 \pm 4$ & $44 \pm 7$ & $46 \pm 8$ \\
\hline 3 & $10 \pm 3$ & $32 \pm 2$ & $52 \pm 2$ & $7 \pm 2$ & $0 \pm 0$ & $13 \pm 4$ & $55 \pm 6$ & $32 \pm 3$ \\
\hline 4 & $19 \pm 11$ & $31 \pm 4$ & $38 \pm 3$ & $12 \pm 6$ & $0 \pm 0$ & $9 \pm 10$ & $59 \pm 15$ & $32 \pm 8$ \\
\hline 5 & $14 \pm 2$ & $40 \pm 7$ & $34 \pm 8$ & $12 \pm 3$ & $0 \pm 0$ & $1 \pm 0$ & $66 \pm 15$ & $33 \pm 15$ \\
\hline 6 & $18 \pm 0$ & $32 \pm 2$ & $36 \pm 1$ & $14 \pm 1$ & $2 \pm 0$ & $5 \pm 3$ & $57 \pm 3$ & $37 \pm 1$ \\
\hline 7 & $17 \pm 4$ & $25 \pm 5$ & $35 \pm 5$ & $23 \pm 10$ & $0 \pm 0$ & $10 \pm 1$ & $56 \pm 3$ & $33 \pm 3$ \\
\hline 8 & $25 \pm 8$ & $37 \pm 11$ & $28 \pm 7$ & $10 \pm 1$ & $0 \pm 0$ & $9 \pm 3$ & $67 \pm 5$ & $25 \pm 2$ \\
\hline 9 & $10 \pm 2$ & $18 \pm 6$ & $54 \pm 8$ & $18 \pm 2$ & $0 \pm 0$ & $1 \pm 1$ & $83 \pm 8$ & $16 \pm 7$ \\
\hline 10 & $18 \pm 6$ & $26 \pm 6$ & $38 \pm 6$ & $18 \pm 8$ & $0 \pm 0$ & $3 \pm 2$ & $73 \pm 4$ & $23 \pm 3$ \\
\hline 11 & $5 \pm 1$ & $45 \pm 3$ & $28 \pm 6$ & $22 \pm 7$ & $2 \pm 1$ & $2 \pm 0$ & $39 \pm 6$ & $58 \pm 5$ \\
\hline 12 & $31 \pm 21$ & $39 \pm 21$ & $21 \pm 11$ & $9 \pm 1$ & $1 \pm 1$ & $1 \pm 0$ & $65 \pm 14$ & $33 \pm 12$ \\
\hline 13 & $8 \pm 7$ & $65 \pm 5$ & $20 \pm 1$ & $6 \pm 2$ & $1 \pm 0$ & $19 \pm 11$ & $21 \pm 2$ & $60 \pm 9$ \\
\hline 14 & $9 \pm 2$ & $27 \pm 17$ & $53 \pm 19$ & $11 \pm 0$ & $0 \pm 0$ & $5 \pm 1$ & $68 \pm 10$ & $27 \pm 10$ \\
\hline 15 & $5 \pm 2$ & $21 \pm 1$ & $61 \pm 7$ & $12 \pm 6$ & $2 \pm 0$ & $6 \pm 2$ & $87 \pm 4$ & $6 \pm 2$ \\
\hline 16 & $8 \pm 4$ & $41 \pm 16$ & $24 \pm 4$ & $28 \pm 14$ & $0 \pm 0$ & $2 \pm 3$ & $49 \pm 5$ & $49 \pm 8$ \\
\hline 17 & $13 \pm 2$ & $8 \pm 3$ & $66 \pm 8$ & $13 \pm 4$ & $2 \pm 2$ & $2 \pm 1$ & $92 \pm 3$ & $5 \pm 1$ \\
\hline 18 & $19 \pm 11$ & $22 \pm 12$ & $53 \pm 24$ & $7 \pm 2$ & $0 \pm 0$ & $5 \pm 4$ & $75 \pm 6$ & $20 \pm 6$ \\
\hline 19 & $11 \pm 5$ & $20 \pm 9$ & $49 \pm 9$ & $20 \pm 10$ & $2 \pm 1$ & $1 \pm 1$ & $81 \pm 5$ & $16 \pm 7$ \\
\hline
\end{tabular}




\section{Table 3}

Relative abundance (mean \pm SE) of nematodes in adult length, adult shape and life history categories at 19 stations in the southwestern North Sea.

C-p = coloniser-persister score (Bongers et al., 1991, 1995)

\begin{tabular}{|c|c|c|c|c|c|c|c|c|c|c|c|}
\hline \multirow[t]{2}{*}{ Station } & \multicolumn{4}{|c|}{ Adult length } & \multicolumn{3}{|c|}{ Adult shape } & \multicolumn{4}{|c|}{ Life history strategy } \\
\hline & $>1 \mathrm{~mm}$ & $1-2 \mathrm{~mm}$ & $2-4 \mathrm{~mm}$ & $>4 \mathrm{~mm}$ & stout & slender & long/thin & c-p 2 & c-p 3 & c-p 4 & c-p 5 \\
\hline 1 & $29 \pm 5$ & $55 \pm 4$ & $12 \pm 1$ & $5 \pm 3$ & $4 \pm 1$ & $86 \pm 3$ & $10 \pm 3$ & $47 \pm 7$ & $38 \pm 2$ & $14 \pm 8$ & $1 \pm 1$ \\
\hline 2 & $18 \pm 3$ & $57 \pm 7$ & $21 \pm 5$ & $5 \pm 1$ & $2 \pm 1$ & $90 \pm 2$ & $8 \pm 2$ & $56 \pm 5$ & $33 \pm 6$ & $11 \pm 3$ & $1 \pm 1$ \\
\hline 3 & $34 \pm 6$ & $57 \pm 5$ & $8 \pm 2$ & $1 \pm 1$ & $8 \pm 2$ & $89 \pm 2$ & $4 \pm 1$ & $56 \pm 13$ & $33 \pm 10$ & $10 \pm 4$ & $1 \pm 1$ \\
\hline 4 & $19 \pm 6$ & $54 \pm 13$ & $22 \pm 11$ & $5 \pm 3$ & $4 \pm 2$ & $80 \pm 8$ & $16 \pm 9$ & $48 \pm 9$ & $26 \pm 1$ & $25 \pm 10$ & $1 \pm 1$ \\
\hline 5 & $13 \pm 1$ & $65 \pm 2$ & $20 \pm 2$ & $1 \pm 0$ & $1 \pm 1$ & $85 \pm 4$ & $14 \pm 3$ & $62 \pm 5$ & $15 \pm 6$ & $22 \pm 2$ & $2 \pm 1$ \\
\hline 6 & $24 \pm 3$ & $52 \pm 3$ & $22 \pm 2$ & $3 \pm 1$ & $12 \pm 4$ & $69 \pm 2$ & $19 \pm 2$ & $44 \pm 4$ & $28 \pm 2$ & $26 \pm 2$ & $2 \pm 1$ \\
\hline 7 & $26 \pm 2$ & $53 \pm 4$ & $18 \pm 5$ & $3 \pm 1$ & $11 \pm 6$ & $77 \pm 5$ & $13 \pm 3$ & $47 \pm 7$ & $37 \pm 7$ & $15 \pm 6$ & $1 \pm 1$ \\
\hline 8 & $24 \pm 2$ & $48 \pm 6$ & $26 \pm 8$ & $2 \pm 1$ & $4 \pm 2$ & $74 \pm 4$ & $22 \pm 5$ & $51 \pm 6$ & $24 \pm 5$ & $25 \pm 6$ & $0 \pm 0$ \\
\hline 9 & $9 \pm 2$ & $74 \pm 7$ & $17 \pm 5$ & $0 \pm 0$ & $0 \pm 0$ & $91 \pm 3$ & $9 \pm 3$ & $57 \pm 7$ & $21 \pm 4$ & $18 \pm 2$ & $3 \pm 2$ \\
\hline 10 & $21 \pm 8$ & $47 \pm 10$ & $29 \pm 14$ & $3 \pm 3$ & $11 \pm 11$ & $69 \pm 4$ & $19 \pm 7$ & $43 \pm 9$ & $38 \pm 11$ & $17 \pm 6$ & $1 \pm 1$ \\
\hline 11 & $13 \pm 2$ & $62 \pm 5$ & $22 \pm 5$ & $3 \pm 1$ & $6 \pm 2$ & $85 \pm 3$ & $9 \pm 3$ & $56 \pm 5$ & $30 \pm 5$ & $14 \pm 1$ & $1 \pm 0$ \\
\hline 12 & $13 \pm 10$ & $45 \pm 17$ & $40 \pm 23$ & $2 \pm 1$ & $8 \pm 8$ & $58 \pm 15$ & $34 \pm 20$ & $48 \pm 16$ & $17 \pm 6$ & $35 \pm 19$ & $0 \pm 0$ \\
\hline 13 & $17 \pm 7$ & $66 \pm 10$ & $15 \pm 3$ & $2 \pm 0$ & $2 \pm 0$ & $93 \pm 1$ & $5 \pm 0$ & $80 \pm 4$ & $13 \pm 3$ & $5 \pm 1$ & $2 \pm 1$ \\
\hline 14 & $35 \pm 9$ & $58 \pm 9$ & $7 \pm 0$ & $0 \pm 0$ & $6 \pm 5$ & $91 \pm 6$ & $3 \pm 0$ & $57 \pm 0$ & $35 \pm 4$ & $8 \pm 4$ & $1 \pm 0$ \\
\hline 15 & $25 \pm 3$ & $68 \pm 2$ & $6 \pm 1$ & $2 \pm 0$ & $5 \pm 0$ & $90 \pm 1$ & $5 \pm 2$ & $56 \pm 1$ & $32 \pm 5$ & $12 \pm 4$ & $1 \pm 0$ \\
\hline 16 & $11 \pm 2$ & $67 \pm 10$ & $21 \pm 12$ & $1 \pm 1$ & $5 \pm 2$ & $86 \pm 5$ & $9 \pm 4$ & $49 \pm 17$ & $25 \pm 10$ & $24 \pm 9$ & $2 \pm 2$ \\
\hline 17 & $31 \pm 2$ & $55 \pm 7$ & $11 \pm 3$ & $3 \pm 2$ & $8 \pm 3$ & $83 \pm 3$ & $9 \pm 0$ & $52 \pm 7$ & $32 \pm 5$ & $15 \pm 3$ & $1 \pm 1$ \\
\hline 18 & $39 \pm 13$ & $50 \pm 10$ & $10 \pm 3$ & $0 \pm 0$ & $13 \pm 3$ & $81 \pm 3$ & $6 \pm 1$ & $48 \pm 8$ & $33 \pm 8$ & $18 \pm 8$ & $2 \pm 2$ \\
\hline 19 & $24 \pm 5$ & $65 \pm 3$ & $10 \pm 6$ & $1 \pm 0$ & $7 \pm 7$ & $86 \pm 9$ & $6 \pm 3$ & $53 \pm 15$ & $20 \pm 3$ & $27 \pm 13$ & $0 \pm 0$ \\
\hline
\end{tabular}


Table 4

Results from ANOSIM analyses: Global $\mathrm{R}$ of differences between nematode assemblages collected at 19 stations in the southwestern North Sea. All R-values were significant at $\mathrm{p}<0.01$.

\begin{tabular}{|l|c|}
\hline & Global R \\
\hline Species & 0.897 \\
Genus & 0.872 \\
Buccal morphology & 0.502 \\
Tail shape & 0.648 \\
Adult length & 0.426 \\
Adult shape & 0.420 \\
Life history strategy & 0.271 \\
Biological traits matrix & 0.697 \\
\hline
\end{tabular}

\section{Table 5}

Results from BIOENV analyses: Spearman rank correlation $\left(\mathrm{r}_{\mathrm{s}}\right)$ and significance level (p) between averaged faunal data and mean environmental variables.

\begin{tabular}{|l|c|c|c|}
\hline & $\mathrm{r}_{\mathrm{s}}$ & $\mathrm{p}$ & Environmental variable \\
\hline Species & 0.652 & 0.01 & Sediment heterogeneity \\
Genus & 0.689 & 0.01 & Sediment heterogeneity \\
Buccal morphology & 0.254 & 0.31 & --- \\
Tail shape & 0.543 & 0.01 & Silt content \\
Adult length & 0.359 & 0.06 & --- \\
Adult shape & 0.076 & 0.84 & --- \\
Life history strategy & 0.318 & 0.15 & -- \\
Biological traits matrix & 0.431 & 0.03 & Median, silt content, depth \\
\hline
\end{tabular}




\section{Figure captions}

Fig. 1. Location of the 19 stations in the southwestern North Sea sampled for nematodes and a suite of environmental variables.

Fig. 2. Mean ( \pm SE) number of species, genera and biological trait groups of nematode assemblages collected at 19 stations in the southwestern North Sea.

Fig. 3. Non-parametric multi-dimensional scaling (MDS) ordination based on the relative abundance of nematode species, genera, functional groups and combined biological traits.

Fig. 4. Non-parametric multi-dimensional scaling (MDS) second-stage ordination of inter-matrix rank correlations. For matrices included see Fig. 3. 


\section{ACCEPTED MANUSCRIPT}

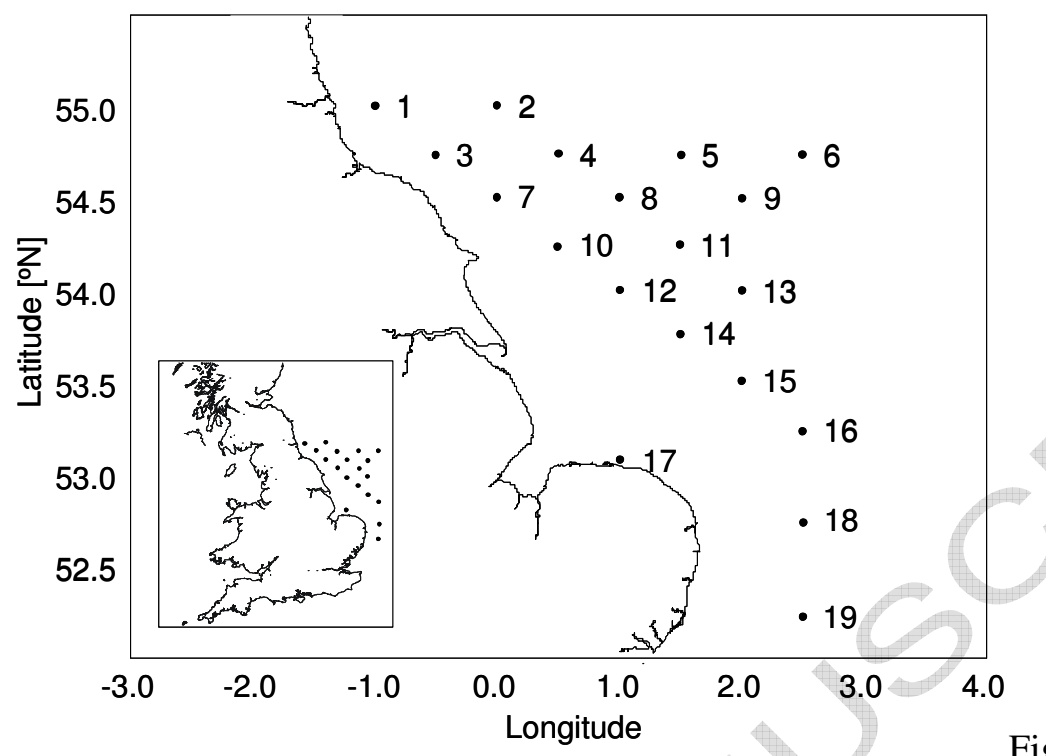

Fig. 1 


\section{ACCEPTED MANUSCRIPT}
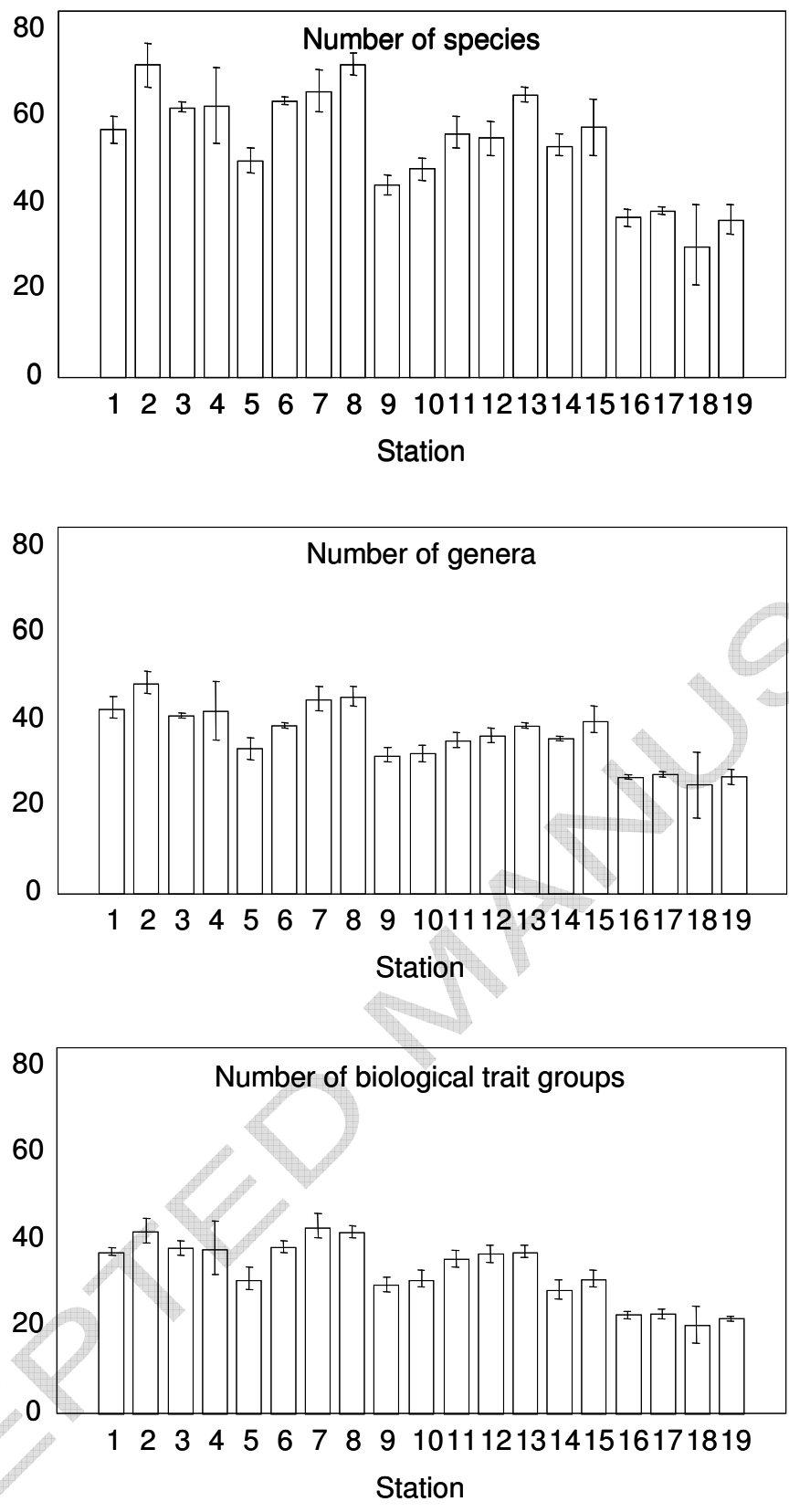

Fig. 2 


\section{ACCEPTED MANUSCRIPT}
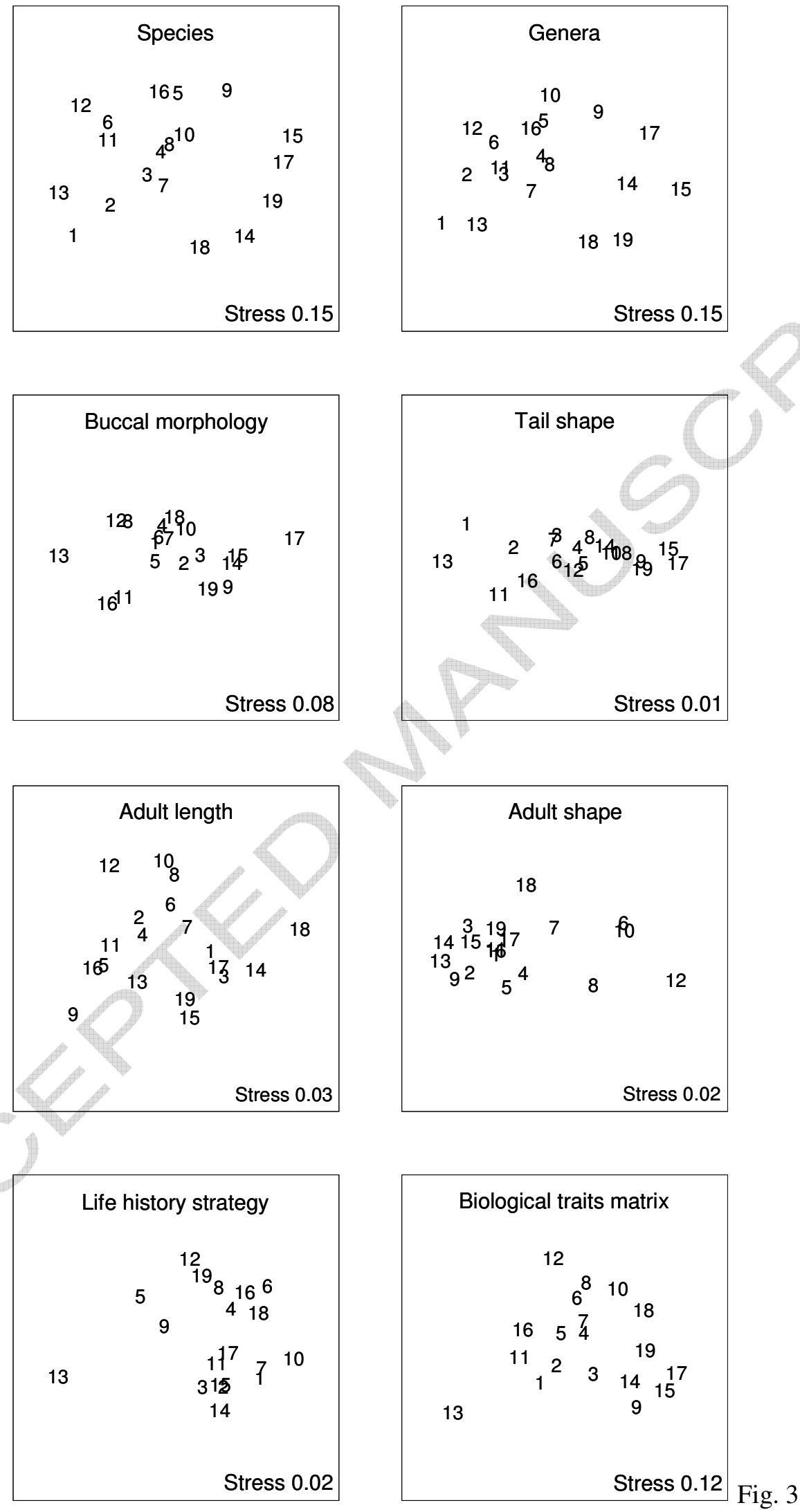


\section{ACCEPTED MANUSCRIPT}

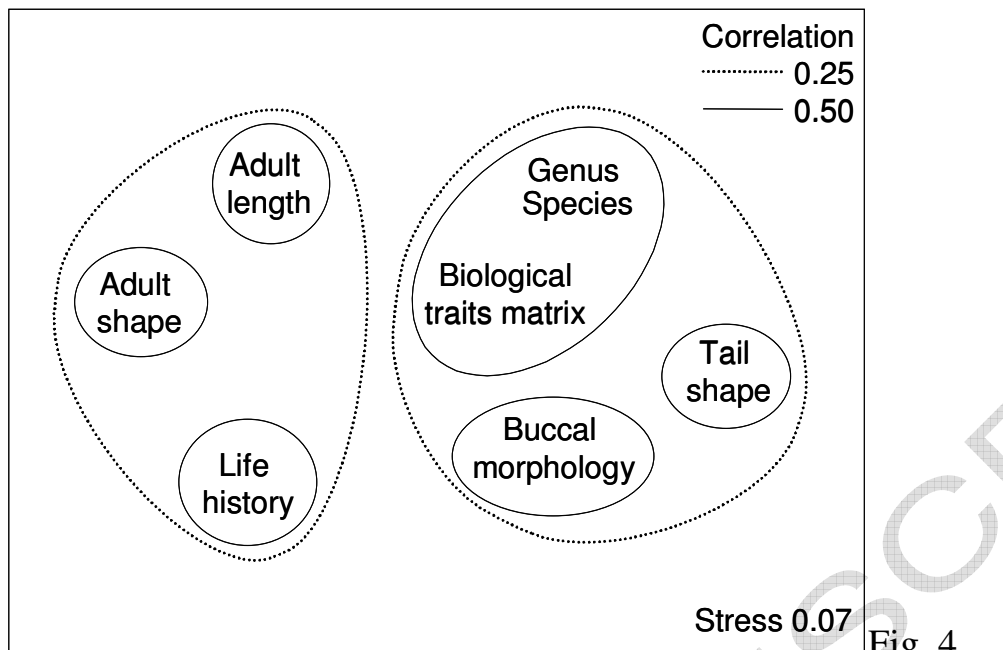

Stress 0.07

Fig. 4 


\section{Appendix}

Biological traits matrix. $1 \mathrm{~A}=$ selective deposit feeders, $1 \mathrm{~B}=$ non-selective deposit feeders, $2 \mathrm{~A}=$ epigrowth feeders, $2 \mathrm{~B}=$ predators (Wieser, 1953). $\mathrm{S} / \mathrm{r}=$ short/round, e/f = elongated/filiform, co $=$ conical, cla $=$ clavate. Adult length is shown in $\mathrm{mm} . \mathrm{St}=$ stout, $\mathrm{sl}=$ slender, $1 / \mathrm{t}=$ long/thin. $\mathrm{C}-\mathrm{p}$ $=$ coloniser-persister score (Bongers et al., 1991, 1995)

\begin{tabular}{|c|c|c|c|}
\hline & & uccal & rphol \\
\hline & $1 \mathrm{~A}$ & 1B & $2 \mathrm{~A}$ \\
\hline Enoplid indet. sp. & 0 & 0 & 0 \\
\hline Mesacanthion diplechma & 0 & 0 & 0 \\
\hline Chaetonema riemanni & 0 & 1 & 0 \\
\hline Anticoma acuminata & 1 & 0 & 0 \\
\hline Dolicholaimus sp. & 0 & 0 & 0 \\
\hline Synonchus fasciculatus & 0 & 0 & 1 \\
\hline Halalaimus gracilis & 1 & 0 & 0 \\
\hline Halalaimus longicaudatus & 1 & 0 & 0 \\
\hline Nemanema cylindraticaudatum & 1 & 0 & 0 \\
\hline Oxystomina asetosa & 1 & 0 & 0 \\
\hline Oxystomina elongata & 1 & 0 & 0 \\
\hline Thalassoalaimus sp. & 1 & 0 & 0 \\
\hline Belbolla sp. & 0 & 0 & 0 \\
\hline Pareurystomina sp. & 0 & 0 & 0 \\
\hline Eurystomina terricola & 0 & 1 & 0 \\
\hline Bathylaimus capacosus & 0 & 1 & 0 \\
\hline Bathylaimus tenuicaudatus & 0 & 1 & 0 \\
\hline Tripyloides sp. & 0 & 1 & 0 \\
\hline Adoncholaimus sp. & 0 & 0 & 0 \\
\hline Oncholaimellus sp. & 0 & 0 & 0 \\
\hline Viscosia abyssorum & 0 & 0 & 0 \\
\hline Viscosia elegans & 0 & 0 & 0 \\
\hline Viscosia glabra & 0 & 0 & 0 \\
\hline Viscosia langrunensis & 0 & 0 & 0 \\
\hline Viscosia viscosa & 0 & 0 & 0 \\
\hline Rhabdodemania major & 0 & 0 & 0 \\
\hline Rhabdocoma riemanni & 1 & 0 & 0 \\
\hline Chromadora nudicapitata & 0 & 0 & 1 \\
\hline Chromadorina germanica & 0 & 0 & 1 \\
\hline Chromadorita nana & 0 & 0 & 1 \\
\hline Chromadorita tentabunda & 0 & 0 & 1 \\
\hline Prochromadorella attenuata & 0 & 0 & 1 \\
\hline Prochromadorella ditlevseni & 0 & 0 & 1 \\
\hline Prochromadorella macroocellata & 0 & 0 & 1 \\
\hline $\begin{array}{l}\text { P. septempapillata } \\
\end{array}$ & 0 & 0 & 1 \\
\hline Neochromadora poecilosoma & 0 & 0 & 1 \\
\hline Neochromadora trichophora & 0 & 0 & 1 \\
\hline Hypodontolaimus sp. & 0 & 0 & 1 \\
\hline $\begin{array}{l}\text { Rhips paraornata } \\
\text { S }\end{array}$ & 0 & 0 & 1 \\
\hline Actinonema pachydermatum & 0 & 0 & 1 \\
\hline Ptycholaimellus ponticus & 0 & 0 & 1 \\
\hline Spilophorella paradoxa & 0 & 0 & 1 \\
\hline Vasostoma sp. & 0 & 1 & 0 \\
\hline Dorylaimopsis punctata & 0 & 0 & 1 \\
\hline Laimella longicaudata & 0 & 0 & 1 \\
\hline Sabatieria elongata & 0 & 1 & 0 \\
\hline Sabatieria ornata & 0 & 1 & 0 \\
\hline Sabatieria punctata & 0 & 1 & 0 \\
\hline Sabatieria praedatrix & 0 & 1 & 0 \\
\hline Setosabatieria hilarula & 0 & 1 & 0 \\
\hline Comesa cuanensis & 0 & 0 & 1 \\
\hline Comesa interrupta & 0 & 0 & 1 \\
\hline Neotonchus sp. & 0 & 0 & 1 \\
\hline Pomponema debile & 0 & 0 & 1 \\
\hline Pomponema multipapillatum & 0 & 0 & 1 \\
\hline Pomponema sedecima & 0 & 0 & 1 \\
\hline Pomponema sp. 1 & 0 & 0 & 1 \\
\hline Nannolaimoides effilatus & 1 & 0 & 0 \\
\hline Marylynnia complexa & 0 & 0 & 1 \\
\hline Paracanthonchus lonicaudatus & 0 & 0 & 1 \\
\hline $\begin{array}{l}\text { Paracanthonchus longus } \\
\text { pas }\end{array}$ & 0 & 0 & 1 \\
\hline Paracanthonchus platti & 0 & 0 & 1 \\
\hline Paracanthonchus thaumasius & 0 & 0 & 1 \\
\hline Paralongicyatholaimus minutus & 0 & 0 & 1 \\
\hline Paracyatholaimus pentodon & 0 & 0 & 1 \\
\hline Paracyatholaimus occultus & 0 & 0 & 1 \\
\hline Halichoanolaimus robustus & 0 & 0 & 0 \\
\hline Gammanema sp. & 0 & 0 & 0 \\
\hline Synonchiella riemanni & 0 & 0 & 0 \\
\hline Richtersia inaequalis & 0 & 1 & 0 \\
\hline Chromaspirina inglisi & 0 & 0 & 0 \\
\hline Leptonemella aphanothecae & 1 & 0 & 0 \\
\hline Epsilonema pustulatum & 1 & 0 & 0 \\
\hline $\begin{array}{l}\text { Pseudonchus sp. } \\
\text { Pe }\end{array}$ & 0 & 0 & 0 \\
\hline Sigmophoranema litorale & 0 & 0 & 1 \\
\hline Sigmophoranema rufum & 0 & 0 & 1 \\
\hline $\begin{array}{l}\text { Desmodora pontica } \\
\text { Desment }\end{array}$ & 0 & 0 & 1 \\
\hline Desmodora schulzi & 0 & 0 & 1 \\
\hline Desmodora tenuispiculum & 0 & 0 & 1 \\
\hline Molgolaimus sp. & 1 & 0 & 0 \\
\hline Parallelocoilas sp. & 0 & 0 & 0 \\
\hline Spirinia parasitifera & 0 & 0 & 1 \\
\hline Spirinia schneideri & 0 & 0 & 1 \\
\hline Aponema torosa & 0 & 0 & 1 \\
\hline Aponema sp. 1 & 0 & 0 & 1 \\
\hline Bolbolaimus teutonicus & 0 & 0 & 0 \\
\hline Calomicrolaimus monstrosus & 0 & 0 & 1 \\
\hline Microlaimus acianaces & 0 & 0 & 1 \\
\hline Microlaimus conothelis & 0 & 0 & 1 \\
\hline Microlaimus marinus & 0 & 0 & 1 \\
\hline Microlaimus turgofrons & 0 & 0 & 1 \\
\hline Microlaimus zosterae & 0 & 0 & 1 \\
\hline Microlaimus sp. 1 & 0 & 0 & 1 \\
\hline
\end{tabular}




\section{ACCEPTED MANUSCRIPT}

Appendix continued

Biological traits matrix. $1 \mathrm{~A}=$ selective deposit feeders, $1 \mathrm{~B}=$ non-selective deposit feeders, $2 \mathrm{~A}=$ epigrowth feeders, 2B = predators (Wieser, 1953). $\mathrm{S} / \mathrm{r}=$ short/round, e/f = elongated/filiform, co $=$ conical, cla $=$ clavate . Adult length is shown in $\mathrm{mm} . \mathrm{St}=$ stout, $\mathrm{sl}=$ slender, $1 / \mathrm{t}=$ long/thin. $\mathrm{C}-\mathrm{p}$ $=$ coloniser-persister score (Bongers et al., 1991, 1995)

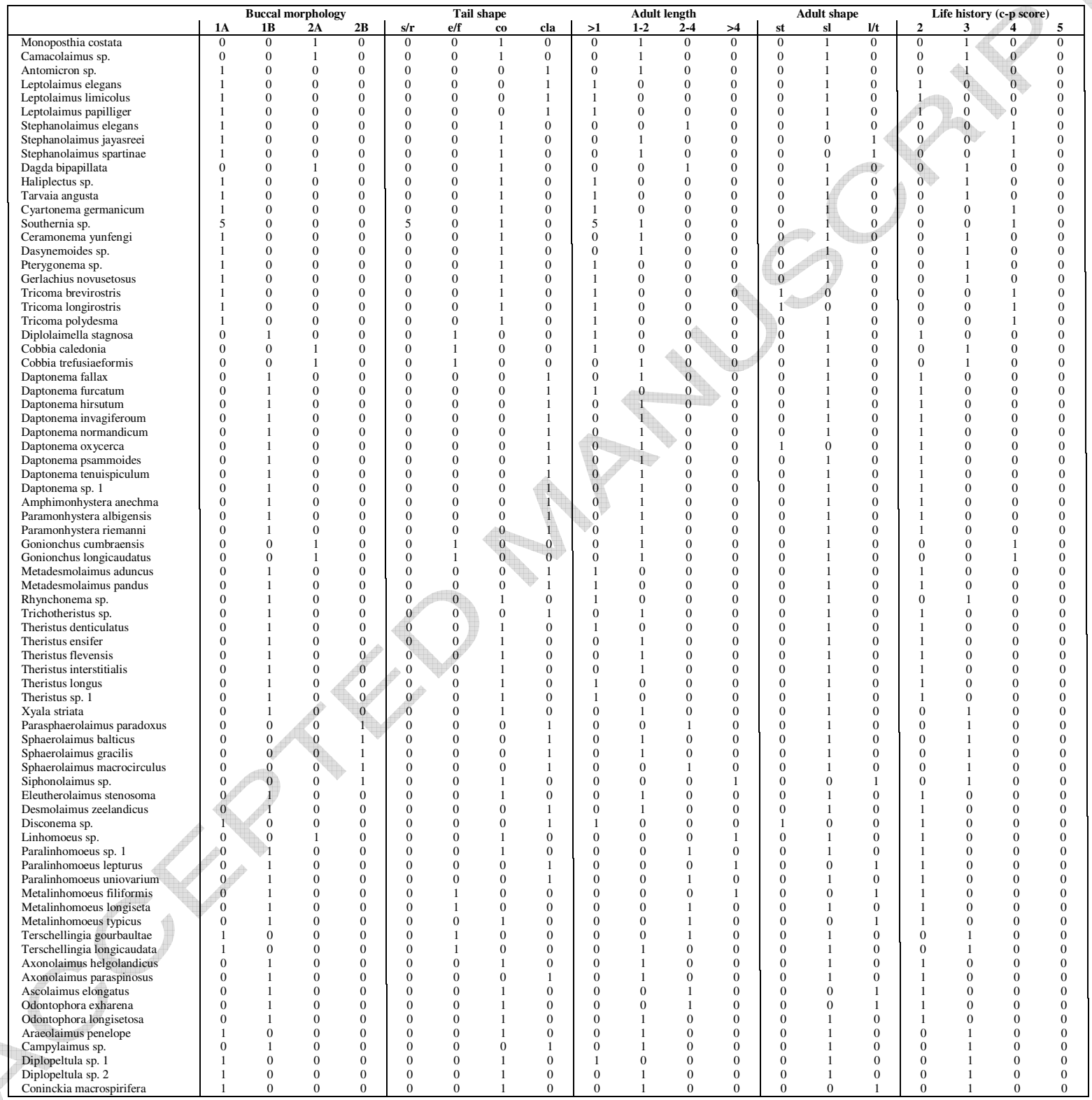

